\title{
ORIGINAL
}

\section{Apoptosis, Keratin, and Occludin during the Development of Furrows in the Circumvallate Papillae and Ductal Lumina in the Glands of von Ebner}

\author{
Yasuko Nagai, Yuko Suzuki, Nobuko Obara and Masako Takeda \\ Department of Oral Anatomy, School of Dentistry, Health Sciences University of Hokkaido \\ (Chief : Prof. Masako Takeda) \\ Tobetsu, Ishikari, Hokkaido 061-0293, Japan
}

(Received on November 26, 2001 ; Accepted on March 26, 2002)

Key words : circumvallate papilla/Ebner's glands/development/apoptosis/occludin

\begin{abstract}
Using mice from embryonic day 18 (E 18) to postnatal day 2 (P 2), we examined apoptosis, keratin and occludin in order to explore the mechanism for the formation of furrows in the circumvallate papillae and ductal lumina in the glands of von Ebner. At E 15, the epithelial cords of the papillae penetrated from the dorsal surface into the connective tissue, and at E 18 the epithelial cords of the glands further extended from the base of the papillary cords. Some small spaces appeared in both cords at E 18 and the spaces increased in number, fused, and enlarged to form furrows and ductal lumina by P 2. Apoptotic cells were distributed around and within the spaces in both cords from the examined E 18 to P 2, playing a role in deleting useless cells and sculpting. Cytokeratins 8/18 existed in the central cells of both cords after E 18, including a single cell layer around the spaces. These cells contained reticular keratin filaments. Occludin, localized at tight junctions, appeared along the apical parts of the cells around the spaces in both cords after E 18. Cytokeratins 8/18- and occludin-positive cells around the spaces disappeared from the papilla after completion of the furrow at $\mathrm{P} 1$ or $\mathrm{P} 2$; however, they remained unchanged around the ductal lumina of the glands. This cell layer plays a role in maintaining the spaces and providing elasticity in the process of fusion and enlargement of the spaces during development.
\end{abstract}

抄録：舌有郭乳頭の溝と, エブネル腺の導管管腔の形成機構を解明するために, 胎生 18 日から生後 2 日までの マウスを用いて, アポトーシス, ケラチンおよびオクルディンについて調べた。胎生 15 日に, 乳頭の上皮索が舌 背面上皮から結合組織へ侵入し，胎生 18 日にはさらにそこからエブネル腺上皮索が伸びていき，これら乳頭と腺 の上皮索のなかに小さな空陌が出現し、しだいに数を増し, 癒合, 拡大し, 生後 2 日までに溝と腺導管管腔を形 成するにいたった。アポトーシス細胞は, 調べた胎生 18 日から生後 2 日までに扔いて, 乳頭と腺の上皮索の空隙 の周囲や内部に散在しており，不要になった細胞を除去し，形を整える役割を果たすと考えられた。サイトケラ チン 8/18 は, 胎生 18 日以降，乳頭と腺の空隙周囲の一層の細胞を含む上皮索中央部の細胞に存在し，この細胞 には, ケラチンフィラメントが網状に散在していた。密着帯に局在するオクルディンは胎生 18 日以降, 乳頭と腺 上皮索の空隙を囲む細胞の内腔側に発現した。サイトケラチン $8 / 18$ とオクルディンをもつ空隙周囲の細胞層は, 乳頭では生後 1 日または 2 日で溝が形成されると消失してしまったが，腺の導管では管腔完成後も管腔周囲にそ のまま存在した。この細胞層は発達過程において空隙を維持し, その壁に弾力性を与え, 空隙の癒合, 拡大を助 ける役割を果たすものと推測される。 


\section{Introduction}

The tongues of rats and mice have a single circumvallate papilla that lies on the posterior midline and contains many taste buds in the trench wall epithelium. The ducts of the serous salivary glands of von Ebner open into the furrow of this papilla, and their bodies are embedded deep in the underlying muscular tissue. The circumvallate papilla in rats is first detectable at E 15 as an epidermal thickening surrounded by an elliptical ring of epithelial cord that penetrates into the connective tissue ${ }^{1}$. The penetrating epithelial cord then splits to form the inner and outer trench walls of the papilla in the early postnatal days. The mechanisms of the formation of the papillary furrows and the ductal lumina of the glands remain unclear. The ductal lumina of the glands of von Ebner develop during the late prenatal and early postnatal periods as do papillary furrows in mice. On the other hand, lumen formation in the major salivary glands such as the submandibular gland, begins earlier at prenatal day 14 or $15^{2)}$. Thus, we examined the development of the papillary furrows and the ductal lumina of the glands of von Ebner by using identical sections of tongue tissue containing circumvallate papillae.

Apoptosis is induced by various stimuli, and is characterized by the fragmentation of genomic DNA into oligonucleosomal-sized pieces ${ }^{3-5)}$. Apoptosis, often called "programmed cell death", in developmental processes has been shown to occur in the elimination of interdigital webs during chick embryo limb development ${ }^{6)}$, palatal fusion ${ }^{7-9)}$, and the elimination of neurons during development of the central and peripheral nervous systems ${ }^{10}$. Jaskoll and Melnick ${ }^{2)}$ reported that the formation of ductal and acinar lumina in the submandibular glands during embryonic development was associated with apoptosis. However, there have been no reports concerning apoptosis during the development of papillary furrows. Therefore, we examined whether apoptosis is involved in the formation of the papillary furrrow as well as the ductal lumen of von Ebner's glands.

Epithelial cells contain keratin intermediate $(10 \mathrm{~nm}$ in diameter) filaments that connect with desmosomal transmembrane glycoproteins, desmocollins, and desmogleins through desmoplakin; and these filaments are distributed throughout the cytoplasm and contribute to the cytoskeletal architecture ${ }^{11-15}$. Keratins are composed of a group of more than 20 keratin polypeptides with molecular weights of $40-70 \mathrm{kD}$, and $2-10$ keratin subunits are present in a given epithelium. The types of keratin subunits vary with the region and changes during embryological development ${ }^{11-15}$. In addition, the aggregation and distribution pattern of keratin filaments observed by transmission electron microscopy reflect differences in the keratin subtypes that comprise these filaments ${ }^{16-18}$. In our previous study ${ }^{18)}$ using the major salivary glands and von Ebner's glands of adult mice, luminal cells of the ducts were positive when stained with PKK 1 antibody (recognizing 40, 45 and $52.5 \mathrm{kD}$ keratin subunits) and contained reticular keratin filaments, and basal cells were nonreactive with PKK 1 and contained dense aggregated bundles of filaments which played a role in supporting the architecture of the ducts.

Occludin $(60-65 \mathrm{kD})$ is one of the transmembrane proteins localized at the tight junction or zonula occludens $^{19-21)}$. The tight junction forms a border between the apical and basolateral cell surface, creating polarization of the epithelial cells, and works as a barrier against the diffusion of solutes through the paracelluar pathway ${ }^{19}$. The tight junction exists in the cells surrounding the lumina of the ducts and acini of the salivary glands. On the other hand, the wall cells around the papillary furrows in adults have no tight junctions. It is unclear whether the cells around the spaces in the developing papillary cords, which are reported to react with the antibody against the $45 \mathrm{kD}$ keratin subunit ${ }^{17}$, possess tight junctions. Also, it is unknown when tight junctions appear in the cells around the spaces of the developing gland cords, and whether they contain the same keratin subunits as in adult mice.

Thus, using mice from E 18 to P 2, we examined apoptosis by DNA nick end labeling (TUNEL) and 52.5 and $45.5 \mathrm{kD}$ keratin subunits, as well as occludin, by immunocytochemistry during the development of furrows in the circumvallate papillae and ductal 
lumina in the glands of von Ebner. In addition, we observed the distribution pattern of keratin filaments and tight junctions by electron microscopy.

\section{Materials and Methods}

DdY-mice were purchased (Sankyo Labo, Sapporo, Japan) and housed in rooms with controlled temperature $\left(25^{\circ} \mathrm{C}\right)$ and humidity $(60 \%)$. They received food and water ad libitum and were kept at a diurnal light schedule (12-h light: 12 -h dark cycle) before use. A total of 42 mice from embryonic day 13 to postnatal day 2 were used. Prenatal mice were obtained from 13 days to 18 days of gestation, with day 0 of gestation defined as the mating day. Pregnant mice were anesthetized with chloroform, and their fetuses were removed. The fetal and early postnatal mice were killed by decapitation. Their tongues were excised, and small blocks containing the circumvallate papillae were cut and fixed in $4 \%$ paraformaldehyde buffered with $0.1 \mathrm{M}$ sodium phosphate $(\mathrm{pH} 7.4)$ for $2 \mathrm{~h}$ at $4^{\circ} \mathrm{C}$. After embedding in paraffin, frontal and sagittal sections were cut to $8-\mu \mathrm{m}$ thickness, stained with hematoxylin and eosin, and observed under a light microscope.

\section{DNA nick end labeling}

Some frontal sections from E 18 to $\mathrm{P} 2$ were incubated with $5 \mu \mathrm{g} / \mathrm{m} l$ proteinase $\mathrm{K}$ (Takara Biochemicals, Ootsu, Japan) for $4 \mathrm{~min}$ at room temperature and then treated with $2 \%$ hydrogen peroxide for $5 \mathrm{~min}$ at room temperature. The reagents provided in the Apop Tag ${ }^{\mathrm{TM}}$ in situ apoptosis detection kit (Intergen Company, NY, USA) were used. This method of DNA nick end labeling is based on the TUNEL assay of Gavrieli, et al. ${ }^{22)}$, but the digoxigenin/anti-digoxigenin system was used instead of the avidin/biotin system of Gavrieli. The sections were immersed in equilibration buffer, which contained potassium cacodylate (dimethylarsinic acid) as a buffer, for $15 \mathrm{sec}$ at room temperature, and then incubated in a solution of terminal deoxynucleotidyl transferase (TdT) and digoxigenin-11-dUTP and dATP at $37^{\circ} \mathrm{C}$ for $1 \mathrm{~h}$ in a humidified chamber. The reaction was terminated by incubation in a stop/wash buffer for $30 \mathrm{~min}$ at $37^{\circ} \mathrm{C}$.
The sections were then incubated in peroxidaseconjugated anti-digoxigenin in a humidified chamber for $30 \mathrm{~min}$ at room temperature, washed in phosphatebuffered saline (PBS, pH 7.2), stained with $0.02 \%$ 3,3'-diaminobenzidine tetrahydrochloride (DAB) in the presence of $0.005 \%$ hydrogen peroxide in $0.05 \mathrm{M}$ TRIS- $\mathrm{HCl}$ buffer $(\mathrm{pH}$ 7.6) for $5 \mathrm{~min}$ at room temperature, and examined under a light microscope.

\section{Immunocytochemistry}

Other frontal sections from E 15 to $\mathrm{P} 2$ were immersed in $0.01 \mathrm{M}$ boiled citrate buffer for $10 \mathrm{~min}$ and incubated with polyclonal guinea pig antibody against cytokeratins $8 / 18$ [antigen source : cytokeratin 8/18 filaments, reconstituted from purified bovine cytokeratins $8(52.5 \mathrm{kD})$ and $18(45.5 \mathrm{kD})$, Progen Biotechnik GMBH, Heidelberg, Germany] at a dilution of $1: 50$ with TRIS- $\mathrm{HCl}$ buffer for $2 \mathrm{~h}$ at room temperature. After being washed in TRIS- $\mathrm{HCl}$ buffer, the sections were incubated with biotinylated secondary antibody and then with streptavidin-peroxidase conjugate (Histomouse $^{\mathrm{TM}}$-SP KIT ; Zymed Laboratories Inc., CA, USA), each for $10 \mathrm{~min}$ at room temperature. The sections were washed again in PBS, incubated in a solution of $0.02 \% \mathrm{DAB}$ in the presence of $0.005 \%$ $\mathrm{H}_{2} \mathrm{O}_{2}$ for $5 \mathrm{~min}$ at room temperature, and examined under a light microscope.

Small blocks containing circumvallate papillae from E 18 to P 2 were frozen with a liquid Freon 22 spray, and sectioned at a thickness of $10 \mu \mathrm{m}$ with a cryostat. The sections were then fixed in $95 \%$ ethanol for $30 \mathrm{~min}$ at $4^{\circ} \mathrm{C}$, postfixed in acetone for $1 \mathrm{~min}$ at room temperature, and incubated for $2 \mathrm{~h}$ at $37^{\circ} \mathrm{C}$ with polyclonal rabbit anti-occludin antibody (antigen source : a GST fusion protein containing of the Cterminal 150 amino acids of chicken occludin ; Zymed Laboratories, Inc., CA, USA) at a dilution of $1: 400$ with PBS. After washing in PBS, the sections were treated with FITC-conjugated swine anti-rabbit IgG (DAKO, Kyoto, Japan) for $90 \mathrm{~min}$ at room temperature. The sections were washed again, and examined under a fluorescence microscope.

\section{Electron microscopy}

Blocks containing circumvallate papillae from mice 
of E $18(n=2)$ and $\mathrm{P} 0 \quad(\mathrm{n}=3)$ were fixed in a mixture of $2 \%$ glutaraldehyde and $2 \%$ paraformaldehyde in $0.1 \mathrm{M}$ phosphate buffer $(\mathrm{pH} 7.4)$ for $2 \mathrm{~h}$ at $4^{\circ} \mathrm{C}$, dehydrated in ethanol, and embedded in Epon 812. Thin sections were cut, stained with uranyl acetate followed by lead citrate, and observed under a transmission electron microscope (Hitachi, H-7100).

Blocks from 0 -day mice $(n=4)$ were fixed in $2 \%$ glutaraldehyde in $0.1 \mathrm{M}$ phosphate buffer for $2 \mathrm{~h}$ at $4^{\circ} \mathrm{C}$, and cut at the frontal plane of the papillae. After postfixation in $1 \% \mathrm{OsO}_{4}$ in phosphate buffer for $2 \mathrm{~h}$ at $4^{\circ} \mathrm{C}$, the blocks were dehydrated with ethanol, dried with a critical point dryer (Hitachi, $\mathrm{HCP}-2$ ), sputtercoated with gold with an ion coater (Eiko, IB-3), and observed under a scanning electron microscope (Hitachi, S-3500 N).

\section{Results}

\section{Embryonic day 13-18}

At $\mathrm{E} 13$, the circumvallate papilla was not yet found on the tongue. At E 15, a dome, situated in the center of the posterior part of the tongue, was encircled by a shallow furrow except at the anterior. Solid papillary cords of the epithelial cells extended from the dorsal epithelium into the connective tissue. By E 18, a few slender epithelial cords, rudiment glands of von Ebner, had arisen as a downgrowth connecting with the base of the papillary cords. A few small spaces first appeared in the papillary and gland cords at E 18 (Fig. 1). TUNEL-positive apoptotic cells were observed near the spaces in both cords and at the outermost layer of the dorsal surface epithelium in the papilla where the cells were nonkeratinized (Fig. 2). Cytokeratin 8/18positive cells were present in the central parts of the papillary and gland cords, including the circumference of the spaces, although the basal cells adjacent to the basement membrane in these cords were nonreactive with this antibody (Fig. 3). Immunofluorescence of the anti-occludin antibody was observed along the cells lining the spaces in the papillary and gland cords (Figs. 4, 5).

\section{Histology at $P 0,1$, and 2}

At postnatal day 0 , irregular spaces in the papilla were arranged in a vertical row in the frontal sections (Fig. 6), and in the sagittal sections, they were arranged horizontally in several rows in the cords, with slender gland cords connecting with the base (Fig. 7). These spaces were in the process of fusing together and took on an overall reticular aspect. The spaces in the gland cords had also fused together to form the ductal lumen. Most of the wall of the duct lumen was surrounded by irregularly formed cells ; and a part of the wall, by squamous cells.

By P 1 and 2, the spaces had fused and grown larger in the papillary cords, and some fused spaces led to the shallow furrows (Fig. 9). At P 2, most of the furrows were complete; however, a few spaces not yet connected with the surface furrows remained at the bottom of the cords (Fig. 10). The gland cords had ramified and increased in number, and all of the cords had formed ductal lumina; but acini were not yet observed in the terminal portion of the cords at P 2 .

\section{DNA nick end labeling (TUNEL) at $P$,, 1 , and 2}

TUNEL-positive cells were observed around and within the spaces in the papillary cords and also in the unkeratinized outermost layer of the dorsal surface epithelium at $\mathrm{P} 0,1$, and 2 (Figs. 11, 12). At $\mathrm{P} 1$ and 2, when the outermost layer had become keratinized, the number of positive cells decreased or disappeared in the dorsal surface. At P 1 and 2, TUNEL-positive cells were found in the unkeratinized outermost layer of the trench wall where the formation of deep furrows was complete (Fig. 12). Positive cells in the gland cords were observed near the spaces at $\mathrm{P} 0,1$ and 2 (Fig. 13).

\section{Immunocytochemistry at $P 0,1$, and 2}

Cytokeratin 8/18-positive cells were found in a single layer around the spaces of the papillary cords at $\mathrm{P} 0,1$, and 2 (Figs. 8, 14). At $\mathrm{P} 2$, there were no positive cells in the trench wall where the fused spaces had connected with the oral cavity, and taste bud cells then appeared in the trench wall and revealed a positive reaction (Fig. 14). Positive cells in the gland cords were longitudinally present in the central parts circumscribing the spaces at $\mathrm{P} 0,1$ and 2 (Figs. 8, 14, 

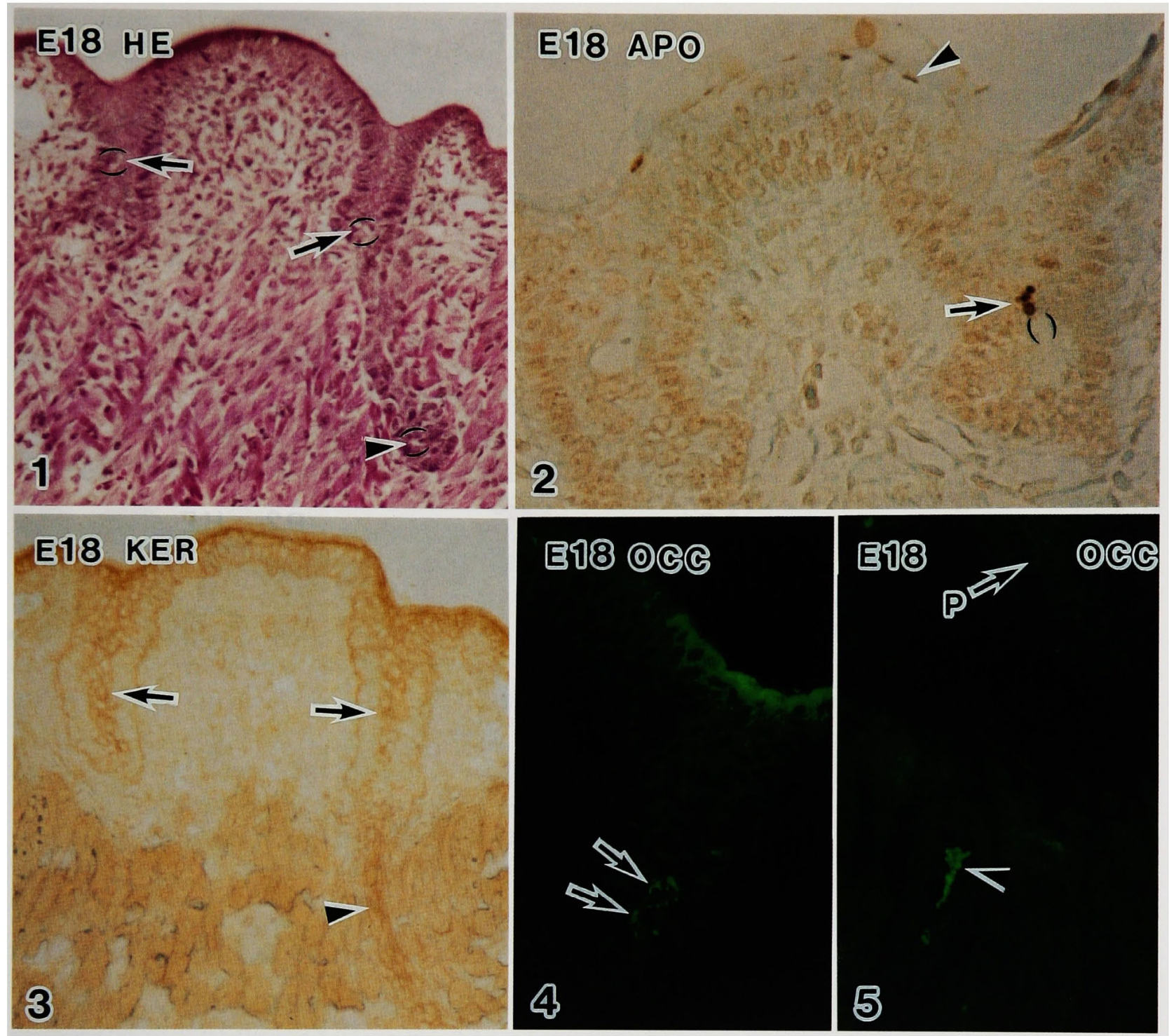

Fig. 1 E 18. HE staining. Small spaces (parentheses) are seen in the papillary (arrows) and gland cords (arrowhead). $\times 150$

Fig. 2 E 18. DNA nick-end labeling. Apoptotic cells are seen around a space (parentheses) in the papillary cord (arrow) and at the dorsal surface (arrowhead). $\times 300$

Fig. 3 E 18. The anti-cytokeratins $8 / 18$ antibody reacts with the cells in the central parts of the papillary (arrows) and gland (arrowhead) cords. $\times 150$

Fig. 4 E 18. The immunofluorescence of occludin is seen along the spaces in the papillary cord (arrows). $\times 300$

Fig. 5 E 18. Occludin is seen in the gland cord (arrowhead). P : papillary cord. $\times 300$

15). After formation of the ductal lumina at $\mathrm{P} 1$ or 2 , the single cell layer around the lumen still revealed a positive reaction; but basal cells were negative (Fig. 14).

The immunofluorescence of the anti-occludin antibody was distributed in a spot or linear pattern at the apical part of the cells around the spaces in the papillary and gland cords and gradually increased with the fusion of the spaces at $\mathrm{P} 0$ and 1 (Figs. 16, 18). At $\mathrm{P} 2$, the distinct fluorescence disappeared in the trench wall of the papilla where the fused spaces had connected with the oral cavity. However, on the 


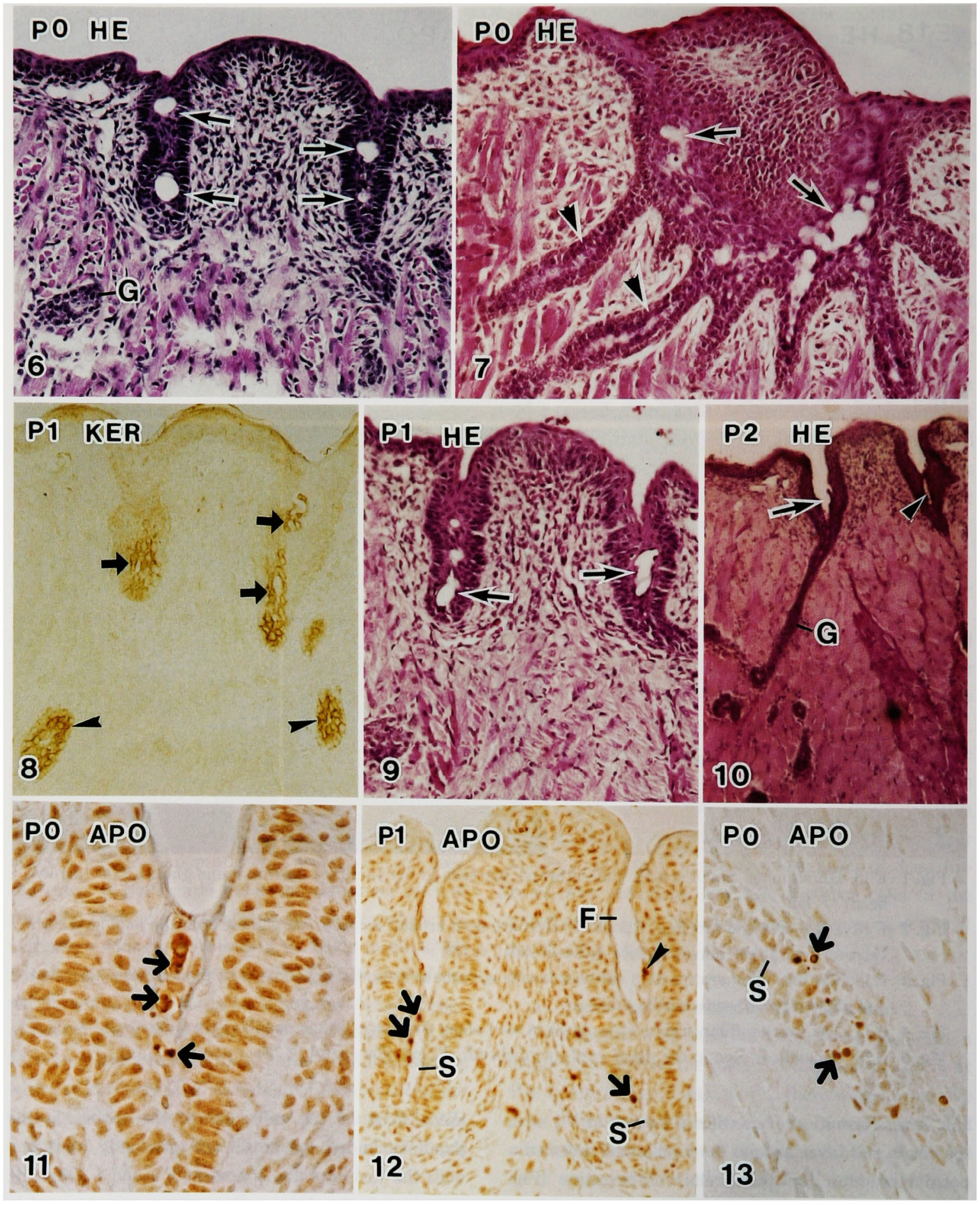


dorsal surface and trench wall epithelium, weak fluorescence was found in a dotted or linear pattern in the cell layers near the surface (Fig. 17). The fluorescence in the gland cords expanded together with the formation of the ductal lumen at P 1 and 2 (Fig. 18).

\section{Electron microscopy}

At E 18 and P 0, transmission electron microscopic observation showed irregular fused spaces in the papillary cords, and apoptotic cells with condensed nuclei in the spaces (Fig. 19). The cytoplasm of the cells surrounding the spaces contained a complicated pattern of reticular intermediate filaments (Fig. 20). On the other hand, the cells away from the spaces possessed densely aggregated bundles of filaments. Junctional complexes, tight junctions, intermediate junctions, and desmosomes were observed between the adjacent cells surrounding the spaces (Fig. 20). All cells in the cords had desmosomes between adjacent cells. At $\mathrm{P} 2$, in the portion where the furrows were complete, tight junctions were not found between adjacent cells in the trench wall ; and the cells abutting the furrows contained densely aggregated bundles as did the basal cells. In the gland cords, the cells surrounding the space contained a complicated network of reticular filaments ; and in the basal cells, densely aggregated bundles of filaments (Fig. 21). Tight junctions were observed between adjacent cells surrounding the space (Fig. 22).

Scanning electron microscopic observation of day- 0 specimens revealed cells that projected into the space of the papillary cord and had a smooth surface similar to apoptotic cells (Fig. 23).

\section{Discussion}

\section{Apoptosis}

In the mouse circumvallate papilla at E 15, the epithelial cords of the papillae penetrated from the dorsal surface into the connective tissue, and at E 18 the epithelial cords of von Ebner's glands developed as a downgrowth connecting with the base of the papillary cords. Some small spaces appeared in both cords at E 18 ; and these spaces gradually increased in number, fused, and enlarged to form furrows and ductal lumina by $\mathrm{P} 2$. Jaskoll and Melnick ${ }^{2)}$ observed apoptotic nuclei at sites of lumen formation in the developing ducts of the mouse submandibular gland and suggested that apoptosis was involved in ductal lumina formation together with TNF-R 1 , known as the death receptor. In this study, we observed only a few apoptotic cells around the spaces in the papillary and gland cords. It is possible that apoptosis only plays a role in deleting useless cells and sculpting during the process of fusion and enlargement of the spaces ${ }^{23}$. Ductal lumen formation of the salivary glands may be associated with the passage of saliva through the duct, however this possibility can be excluded, because acinar secretory cells have not yet formed before $\mathrm{P} 2$. Thus, other unknown mechanisms may be involved in the formation of papillary furrows and ductal lumina. On the other hand, Hecht, et al. ${ }^{24)}$

Fig. 6 P 0 . HE staining. Irregular spaces (arrows) are vertically arranged in a row in the frontal section. G : gland cord. $\times 150$

Fig. 7 P 0. HE staining of a sagittal section. Spaces in the papillary cord (arrows) are arranged horizontally in several rows, with slender gland cords (arrowheads) connecting with the base. $\times 300$

Fig. 8 P 1. Cytokeratins $8 / 18$ are seen in the cells surrounding the spaces of the papillary (arrows) and gland (arrowheads) cords. $\times 150$

Fig. 9 P 1 . HE staining. The spaces (arrows) have fused and grown larger in the papillary cords. $\times 150$

Fig. 10 P 2. HE staining. A furrow on one side (arrow) is complete; however, one space on the other side (arrowhead) does not connect with the surface furrow. $G$ : gland cord. $\times 90$

Fig. 11 P 0. DNA nick-end labeling. Apoptotic cells (arrows) are seen in and around the spaces in the papillary cord. $\times 600$

Fig. 12 P 1. DNA nick-end labeling. Apoptotic cells (arrows) are distributed around the spaces (S), and at the outermost layer (arrowhead) of the wall around the shallow furrow (F) in the papilla. $\times 150$

Fig. 13 P 0. DNA nick-end labeling. Apoptotic cells (arrows) are seen in the gland cord. S: duct space. $\times 270$ 


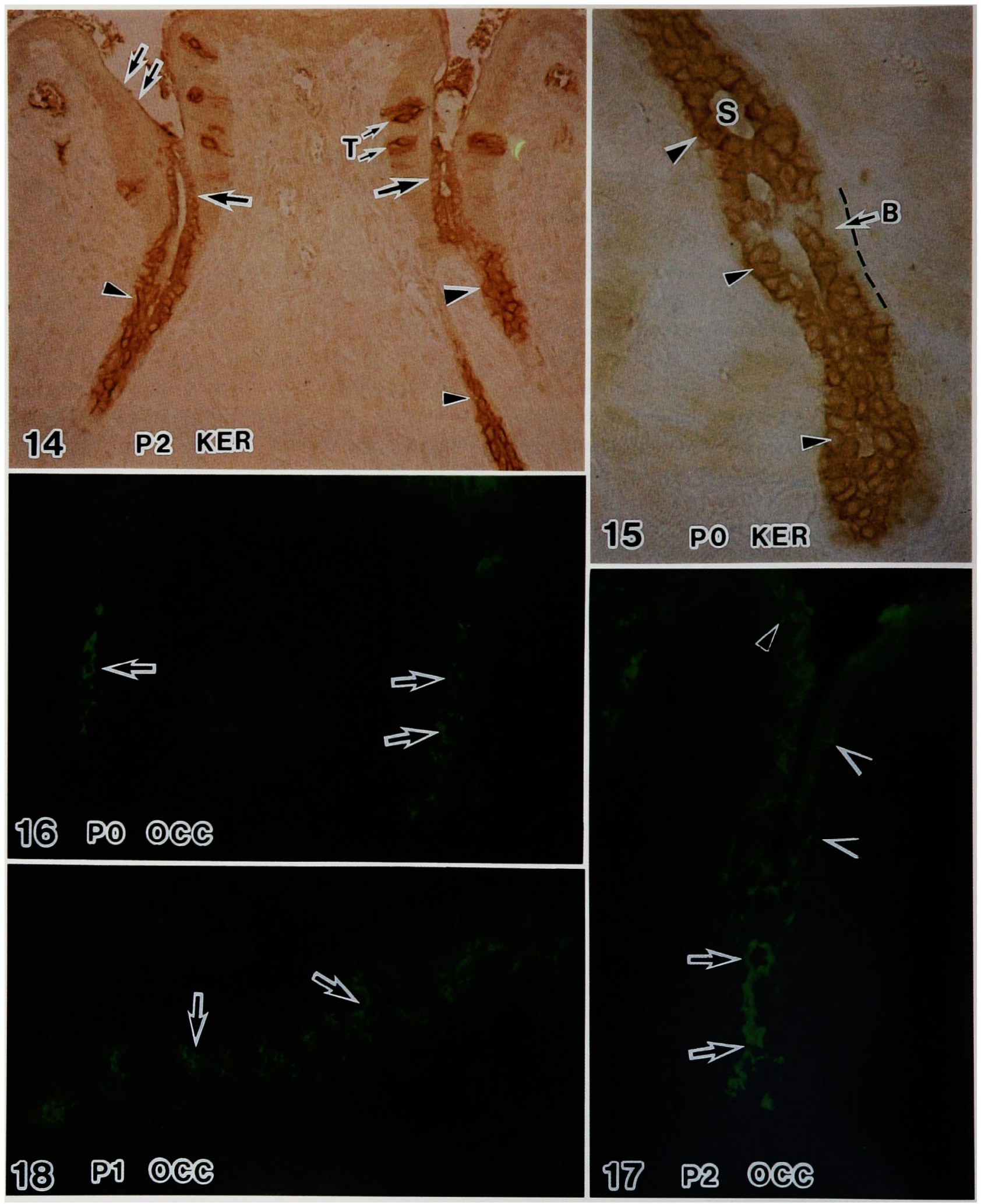


suggested that cell differentiation leading to the mature type of intercalated ducts of the rat submandibular gland is due, at least in part, to apoptosis. Therefore, some of the apoptotic cells observed in the gland cords in this study may be associated with cell differentiation of the gland ducts.
We found apoptotic cells in the outermost layer of the trench wall epithelium in the papilla after formation of the furrow in the early postnatal days. Such apoptotic cells have also been reported in adult mice ${ }^{25}$. Thus, the basal cells in the trench wall divide and move to the outer layers, and the outermost layer

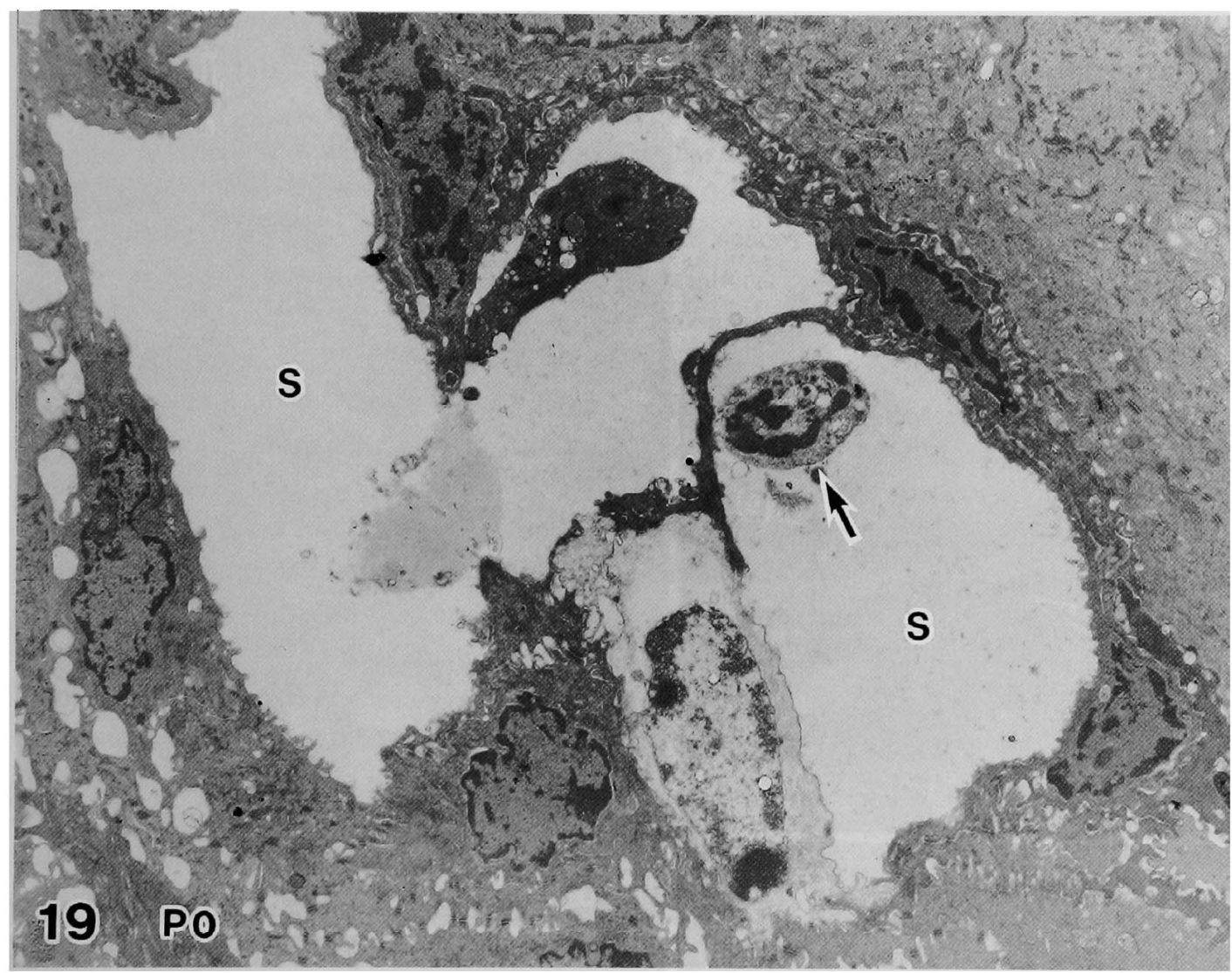

Fig. 19 P 0. Transmission electron micrograph (TEM) of a circumvallate papilla. An apoptotic cell with a condensed nucleus (arrow) is seen in the irregular spaces (S) of the papillary cord. $\times 5,000$

Fig. 14 P 2. Cytokeratin 8/18 positive cells are found in a single cell layer around the spaces of the papillary (arrows) and gland cord (arrowheads). There are no positive cells in the trench wall (double arrows) where the fused spaces have connected with the oral cavity. $T:$ taste buds. $\times 150$

Fig. $15 \mathrm{P}$ 0. Cytokeratin 8/18-positive cells (arrowheads) are present around the spaces (S) of the gland cord in a single layer ; but basal cells (B) are negative. Dotted line, basement membrane. $\times 300$

Fig. $16 \mathrm{P}$ 0. The fluorescence of occludin (arrows) is distributed in a spot or linear pattern around the spaces in the papillary cords. $\times 150$

Fig. 17 P 2. The distinct fluorescence of occludin (arrows) is seen in the central parts of the papillary cord, surrounding the spaces, but is absent from the trench wall where the fused spaces have connected with the oral cavity. Weak fluorescence (arrowheads) is found in the cell layers near the surface of the trench wall and dorsal epithelium. $\times 300$

Fig. 18 P 1. Occludin (arrows) is seen around the spaces of a gland cord. $\times 300$ 
cells die by apoptosis.

\section{Keratin}

During development, cytokeratin 8/18-positive cells already existed in the central areas of the papillary and gland cords, including the cells around the spaces at $\mathrm{E} 18$, and these cells contained reticular filaments, similar to luminal cells of the ducts in adult mice ${ }^{18)}$

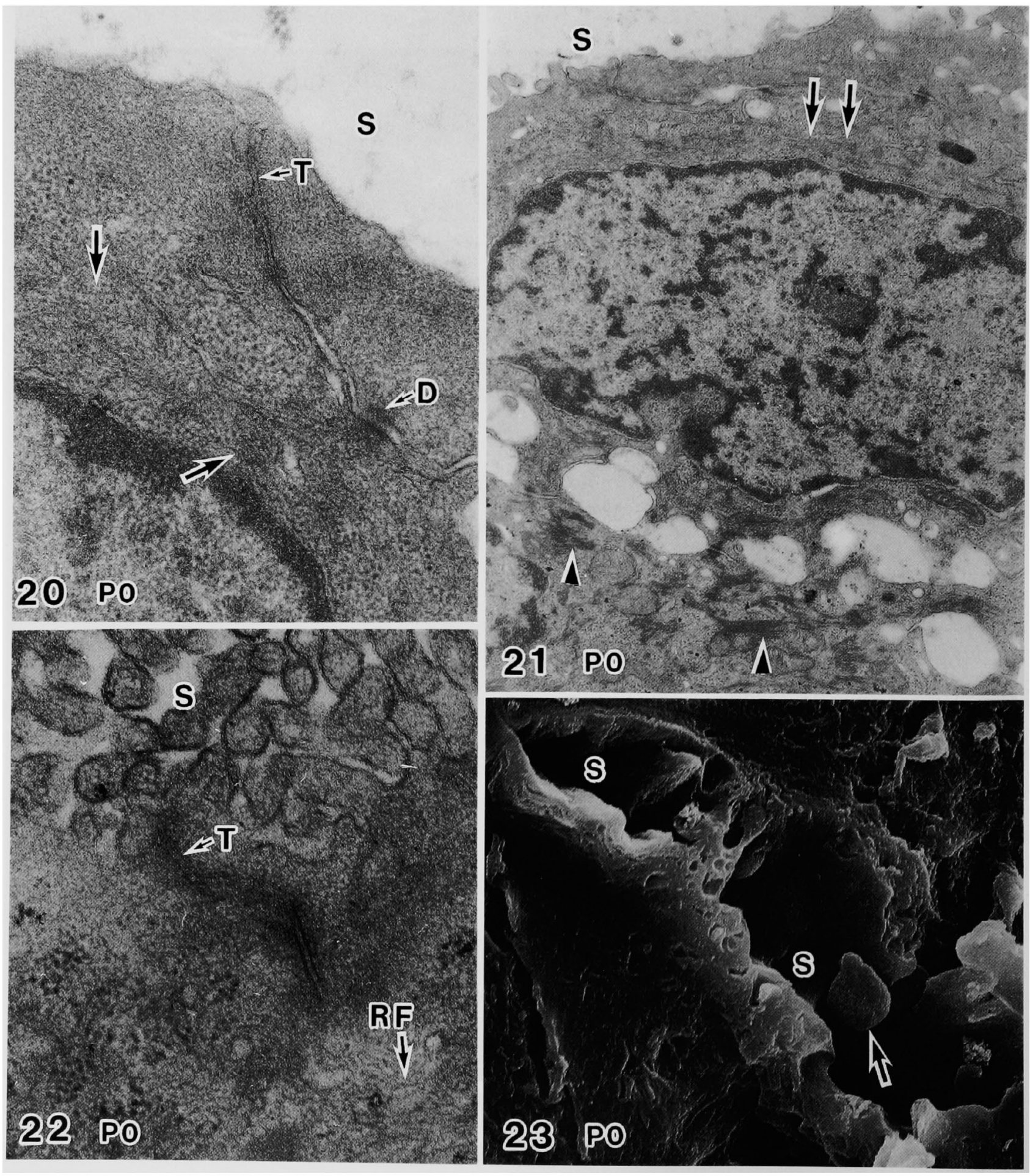


and to the cells around the spaces of the papillary cord as reported in the early postnatal days ${ }^{17}$. These cells may act to help expansion and contraction during the process of fusion and enlargement of the spaces. After completion of the furrows, these cells, having completed their roles, disappeared. Such disappearance of the cells may not be due mainly to apoptosis, but to desquamation from the trench wall surface, because TUNEL-positive cells were few in number in the papillary cords at $\mathrm{P} 1$ or 2 . On the other hand, in the glands, the cells containing reticular filaments still remained around the lumen after completion of the ductal lumina, helping in the contraction of the ductal lumina.

\section{Occludin}

Occludin, claudin, and JAM (junctional adhesion molecule) are known as transmembrane proteins that are localized at the tight junctions ${ }^{19,20,26-28)}$. Occludin has 4 transmembrane domains, and its $\mathrm{C}$-terminal domain binds to ZO-1, ZO-2, ZO-3, which are localized in the immediate vicinity of the plasma mem. brane of tight junctions ${ }^{29-31}$. In this study, occludin appeared along the apical parts of the cells around the spaces in the papillary and gland cords at E 18 when the spaces were formed, and, at the same time, tight junctions (zonula occludens) were observed by electron microscopy at the apical portions between adjacent cells surrounding the spaces. Such a phenomenon, the appearance of spaces accompanied by the formation of tight junctions, has been reported in the follicular lumina of thyroid glands ${ }^{32)}$ and intraepithelial cavities in the thick stratified epithelia of the small intestines during development ${ }^{33)}$. Thus, the apical surface membrane of the cells around the spaces acquired an architecture different from that of the basolateral cell membrane, creating cell polarity. Also, opposing apical cell membranes are unable to make contact via desmosomes across the spaces ; as a result, the spaces are maintained. To generate and maintain this polarized membrane composition, a specific vectorial flow of membrane carriers must be ensured. Many studies have recently shown that various molecules such as SNARE, rab family, $\mu 1 \mathrm{~B}$ and rafts are involved in the mechanism of polarized sorting ${ }^{34,35)}$, however, further analysis will be necessary to resolve this problem. In the papillary cords, occludin-positive cells around the spaces were cytokeratin 8/18-positive and only temporarily present, because they disappeared after completion of the furrows, as mentioned above. There have been no reports concerning such a temporary appearance of cells having tight junctions during development, and this phenomenon remains to be explored.

In this study, after completion of the furrows, weak immunofluorescence of the anti-occludin antibody was observed in the cell layers near the surface of the trench wall and dorsal surface epithelium of the papilla. Morita, et $a l .^{36)}$ reported that occludin was concentrated at cell-cell borders in the most superficial zone of the glanular cell layer in the mouse epidermis after embryonic day 16 and that immunoreplica electron microscopy revealed focal strands (macula occludens) labeled with anti-occludin antibody. Thus, the occludin observed in the trench wall and dorsal surface may also be localized at the macula occludens, and involved in the barrier function to some extent.

In conclusion, apoptotic cell death in the papillary and gland cords could play a role in deleting useless cells and in sculpting during the formation of furrows

Fig. 20 P 0. TEM. A tight junction ( T) and desmosome (D) are seen between adjacent cells surrounding a space (S) in the papillary cord. The cells contain a complicated network of reticulated keratin filaments (arrows). $\times 50,000$

Fig. 21 P 0. TEM. The cells around the space (S) of the gland cord contain a complicated pattern of reticular filaments (arrows); and the basal cells, densely aggregated bundles of filaments (arrowheads). $\times 17,000$

Fig. 22 P 0. TEM. A tight junction ( T) is seen between adjacent cells surrounding the space (S) in the gland duct. $\mathrm{RF}:$ reticular filaments. $\times 61,000$

Fig. 23 P 0. Scanning electron micrograph of a circumvallate papilla. A cell similar in appearance to an apoptotic cell (arrow), which has a smooth surface, projects into a space $(\mathrm{S})$ of the papillary cord. $\times 1,500$ 
in the circumvallate papillae and ductal lumina in the glands of von Ebner. Also, the single layer of cells around the spaces, possessing tight junctions and reticular keratin filaments, may play a role in maintaining the spaces and in providing elasticity in the process of fusion and enlargement of the spaces.

\section{References}

1) Torrey, T.W.: The influence of nerve fibers upon taste buds during embryonic development. Proc. Natl. Acad. Sci. U. S. A. 26:627-634, 1940.

2) Jaskoll, T. and Melnick, M. : Submandibular gland morphogenesis : stage-specific expression of TGF$\alpha / \mathrm{EGF}, \mathrm{IGF}, \mathrm{TGF}-\beta, \mathrm{TNF}$, and IL- 6 signal transduction in normal embryonic mice and the phenotypic effects of TGF- $\beta 2$, TGF- $\beta 3$, and EGFR null mutations. Anat. Rec. 256:252-268, 1999.

3) Kerr, F. R., Wyllie, A. H. and Currie, A. R. : Apoptosis: a basic biological phenomenon with wide-ranging implications in tissue kinetics. $\mathrm{Br}$. J. Cancer 26 : 239-257, 1972.

4) Wyllie, A. H. : Apoptosis : cell death in tissue regulation. J. Pathol. 153 : 313-316, 1987.

5) Ellis, R. E., Yuan, J. and Horvitz, H. R. : Mechanisms and functions of cell death. Annu. Rev. Cell Biol. 7 : 663-698, 1991.

6) Yokouchi, Y., Sakiyama, J., Kameda, T., Iba, H., Suzuki, A., Ueno, N. and Kuroiwa, A. : BMP-2/-4 mediate programmed cell death in chicken limb buds. Development 122 : 3725-3734, 1996.

7) Mori, C., Nakamura, N., Okamoto, Y., Osawa, M. and Shiota, K. : Cytochemical identification of programmed cell death in the fusing fetal mouse palate by specific labelling of DNA fragmentation. Anat. Embroyl (Berl). 190:21-28, 1994.

8) Taniguchi, K., Sato, N. and Uchiyama, Y.: Apoptosis and heterophagy of medial edge epithelial cells of the secondary palatine shelves during fusion. Arch. Histol. Cytol. 58 : 191-203, 1995.

9) Matsumoto, K., Obara, N., Takeda, M. and Kanazawa, M. : Histochemical study of palate development in fetal mice. Higashi Nippon Dent. J. 18 : 293-305, 1999.

10) Oppenheim, R. W. : Cell death during development of the nervous system. Ann. Rev. Neurosci. 14: 453-501, 1991.

11) Sun, T. T., Shih, C. and Green, H. : Keratin cytoskeletons in epithelial cells of internal organs. Proc.
Natl. Acad. Sci. U. S. A. $76: 2813-2817,1979$.

12) Schlegel, R., Banks-Schlegel, S. and Pincus, G. S. : Immunocytochemical localization of keratin in normal human tissues. Lab. Invest. 42: 91-96, 1980.

13) Denk, H., Krepler, R., Lackinger, E., Artlieb, U. and Franke, W. W. : Biochemical and immunocytochemical analysis of the intermediate filament cytoskeleton in human hepatocellular carcinomas and in hepatic neoplastic nodules of mice. Lab. Invest. 46:584-596, 1982.

14) Moll, R., Franke, W. W. and Schiller, D. L. : The catalog of human cytokeratins: patterns of expression in normal epithelia, tumors and cultured cells. Cell 31 : 11-24, 1982.

15) Kouklis, P. D., Hutton, E. and Fuchs, E. : Making a connection direct binding between keratin intermediate filaments and desmosomal proteins. J. Cell Biol. 127 : 1049-1060, 1994.

16) Takeda, M., Obara, N. and Suzuki, Y. : Intermediate filaments in mouse taste bud cells. Arch. Histol. Cytol. 51 : 99-108, 1988.

17) Takeda, M., Obara, N. and Suzuki, Y. : Keratin filaments of epithelial and taste-bud cell in the circumvallate papillae of adult and developing mice. Cell Tissue Res. 260 : 41-48, 1990.

18) Nagai, Y., Suzuki, Y., Obara, N. and Takeda, M. : Keratin filaments in rat salivary glands. Jpn. J. Oral Biol. 38: 97-106, 1996.

19) Matter, K. and Balda, M. S. : Occludin and the functions of tight junctions. Int. Rev. Cytol. 186: 117-146, 1999.

20) Furuse, M., Hirase, T., Itoh, M., Nagafuchi, A., Yonemura, S., Tsukita, S. and Tsukita, S. : Occludin : a novel integral membrane protein localizing at tight junctions. J. Cell Biol. 123: 1777-1788, 1993.

21) Furuse, M., Itoh, M., Hirase, T., Nagafuchi, A., Yonemura, S., Tsukita, S. and Tsukita, S. : Direct association of occludin with $2 \mathrm{O}-1$ and its possible involvement in the localization of occludin at tight junctions. J. Cell Biol. 127 : 1617-1626, 1994.

22) Gavrieli, Y., Sherman, Y. and Ben-Sasson, S. A. : Identification of programmed cell death in situ via specific labeling of nuclear DNA fragmentation. J. Cell Biol. 119 : 493-501, 1992.

23) Jacobson, M. D., Weil, M. and Raff, M. C. : Programmed cell death in animal development. Cell 88: 347-354, 1997.

24) Hecht, R., Connelly, M., Marchetti, L., Ball, W. D. 
and Hand, A. R. : Cell death during development of intercalated ducts in the rat submandibular gland. Anat. Rec. $258: 349-358,2000$.

25) Takeda, M., Suzuki, Y., Obara, N. and Nagai, Y. : Apoptosis in mouse taste buds after denervation. Cell Tissue Res. 286: 55-62, 1996.

26) Furuse, M., Fujita, K., Hiiragi, T., Fujimoto, K. and Tsukita, S. : Claudin-1 and-2: novel integral membrane proteins localizing at tight junctions with no sequence similarity to occludin. J. Cell Biol. 141 : 1539-1550, 1998.

27) Furuse, M., Sasaki, H., Fujimoto, K. and Tsukita, $\mathrm{S}$. : A single gene product, Claudin-1 or -2 , reconstitutes tight junction strands and recruits occludin in fibroblasts. J. Cell Biol. $143: 391-401,1998$.

28) Martin-Padura, I., Lostaglio, S., Schneemann, M., Williams, L., Romano, M., Fruscella, P., Panzeri, C., Stoppacciaro, A., Ruco, L., Villa, A., Simmons, D. and Dejana, E.: Junctional adhesion molecule, a novel member of the immunoglobulin superfamily that distributes at intercellular junctions and modulates monocyte transmigration. J. Cell Biol. 142: 117-127, 1998.

29) Stevenson, B. R., Siliciano, J. D., Mooseker, M. S. and Goodenough, D. A. : Identification of 2O-1: a high molecular weight polypeptide associated with the tight junction (zonula occludens) in a variety of epithelia. J. Cell Biol. 103 : 755-766, 1986.

30) Gumbiner, B., Lowenkopf, T. and Apatira, D. : Identification of a $160 \mathrm{kDa}$ polypeptide that binds to the tight junction protein 20-1. Proc. Natl. Acad. Sci. U. S. A. $88: 3460-3464,1991$.

31) Haskins, J., Gu, L., Wittchen, E. S., Hibbard, J. and Stevenson, B. R. : ZO-3, a novel member of the MAGUK protein family found at the tight junction, interacts with ZO-1 and occludin. J. Cell Biol. 141 : 199-208, 1998.

32) Ishimura, K. and Fujita, H. : Development of cell-tocell relationships in the thyroid gland of the chick embryo. Cell Tissue Res. 198: 15-25, 1979.

33) Yamamoto, M., Toyota, T. and Kataoka, K. : Electron microscope observation on the formation of primitive villi in rat small intestine with special reference to intercellular junctions. Arch. Histol. Cytol. 55: 551-560, 1992.

34) Lafont, F., Verkade, P., Galli, T., Wimmer, C., Louvard, D. and Simons, K. : Raft association of SNAP receptors acting in apical trafficking in Madin-Darby canine kidney cells. Proc. Natl. Acad. Sci. U. S. A. 96:3734-3738, 1999.

35) Ohno, H., Tomemori, T., Nakatsu, F., Okazaki, Y., Aguilar, R. C., Foelsh, H., Mellman, I., Saito, T., Shirasawa, T. and Bonifacino, J. S. : $\mu 1$ B, a novel adaptor medium chain expressed in polarized epithelial cells. FEBS Lett. 449 : 215-220, 1999.

36) Morita, K., Itoh, M., Saitou, M., Ando-Akatsuka, M., Furuse, M., Yoneda, K., Imamura, S., Fujimoto, $\mathrm{K}$. and Tsukita, S. : Subcellular distribution of tight junction-associated proteins (Occludin, ZO-1, ZO-2) in rodent skin. J. Invest. Derm. 110:862-866, 1998. 